DOI: https://doi.org/10.47405/mjssh.v6i7.859

\begin{tabular}{|c|c|}
\hline$\sqrt{104}$ & Malaysian Journal of Social Sciences and Humanities (MJSSH) \\
\hline $\begin{array}{l}\text { Malaysian Journal of } \\
\text { Socai sciences and }\end{array}$ & Volume 6, Issue 7, July 2021 \\
\hline (mJ-sSH) & e-ISSN : 2504-8562 \\
\hline & $\begin{array}{l}\text { Journal home page: } \\
\text { www.msocialsciences.com }\end{array}$ \\
\hline
\end{tabular}

\title{
Keberkesanan Program Imunisasi COVID-19 Kebangsaan di Malaysia Timur
}

\author{
Adi Jafar'1, Fionna George ${ }^{1}$, Aisah Meri ${ }^{1}$, Chong Vun Hung ${ }^{1}$, Mohammad Tahir Mapa ${ }^{1}$, Nordin \\ Sakke', Colonius Atang', Ramli Dollah¹, Eko Prayitno Joko', Zainuddin Baco ${ }^{1}$ \\ ${ }^{1}$ Universiti Malaysia Sabah (UMS)
}

Correspondence: Mohammad Tahir Mapa (herman@ums.edu.my)

\begin{abstract}
Abstrak
Program Imunisasi COVID-19 Kebangsaan (PICK) telah diperkenalkan bermula pada Febuari 2021 lagi. Sehubungan dengan itu, semua rakyat Malaysia secara sukarela diseru untuk menyertai program tersebut. Namun demikian, kadar pendaftaran PICK diperingkat awal khususnya di bahagian Timur Malaysia (Sabah) kurang mendapat sambutan. Bertitik tolak daripada permasalahan tersebut, kajian ini ingin mengenalpasti tahap keberkesanan PICK di Sabah. Dalam pada itu, kajian ini turut meneliti faktor penolak dan penarik yang mempengaruhi keberhasilan program terbabit. Maka dengan itu, seramai 1024 responden telah ditemubual secara dalam talian (google form) dan secara bersemuka menggunakan borang soal selidik. Data mentah yang diperolehi dianalisis secara diskriptif menggunakan Min dan frekuensi. Analisis kajian mendapati tahap Keberkesanan Program Imunisasi COVID-19 Kebangsaan di Sabah adalah pada tahap sederhana dengan nilai indeks petunjuk keberkesanan sebanyak 66.67 peratus. Selain itu, analisis kajian turut mendapati kelemahan media perdana merupakan salah satu faktor utama menyebabkan wujudnya ketidakyakinan masyarakat Sabah menyertai PICK. Walaupun begitu, proses pendaftaran yang mudah dan jaminan terhadap kehalalan vaksin merupakan faktor pendorong (penarik) kepada keberhasilan program tersebut.
\end{abstract}

Kata kunci: COVID-19, imunisasi, vaksin, Malaysia, Sabah, keberkesanan

\section{Effectiveness of The National COVID-19 Immunization Program in East Malaysia}

\begin{abstract}
The National COVID-19 Immunization Programme (PICK) was introduced in February 2021. In this regard, all Malaysians are voluntarily invited to participate in the programme. However, the PICK registration rate at an early stage, especially in East Malaysia (Sabah), received less response. Based on these problems, this study aims to identify the level of effectiveness of PICK in Sabah. At the same time, this study also examines the repulsive and attractive factors that influence the outcome of the programme. A total of 1024 respondents were interviewed online (google form) and face to face using a questionnaire. The raw data obtained were analyzed descriptively using Mean and Frequency. The analysis of the study found that the level of effectiveness of the National COVID-19 Immunization Programme in Sabah is at a moderate level with an effectiveness indicator index value of 66.67 percent. In addition, the analysis of the study also found that the weakness of the mainstream media is one of the main factors causing the existence of distrust of the people of Sabah to participate in PICK. Even so, the simple registration process and assurance of the legality of the vaccine are the driving factors (pull) to the success of the programme.
\end{abstract}


Keywords: COVID-19, immunization, vaccine, Malaysia, Sabah, effectiveness

\section{Pengenalan}

Manusia di muka bumi ini sangat terdedah dengan pelbagai jenis bahaya penyakit termasuklah yang bersifat epidemik dan pandemik. Novel Coronavirus atau COVID-19 merupakan salah satu bahaya biologi yang dikategorikan sebagai pandemik kerana telah menular ke serata dunia termasuklah Malaysia (Jafar et al., 2021). Skala sebaran impak pandemik ini sangat luas melangkaui batasan wilayah ekologi, negara, ekonomi dan masyarakat (Alcántara-Ayala et al., 2021). Kesan penularan wabak ini mendatangkan pelbagai masalah seperti kematian (Nuryana \& Fauzi, 2020), masalah kegemukan (Pausé et al., 2021), masalah psikologi (Sheek-Hussein et al., 2021), masalah kesihatan awam (public health) dan masalah sosio-ekonomi (Wirya, 2020). Oleh hal demikian, kerajaan Malaysia telah mengambil beberapa langkah drastik bagi mengatasi masalah tersebut. Antaranya adalah melalui pengisytiharan Perintah Kawalan Pergerakan (PKP) (Perutusan khas Perdana Menteri, 2020) dan pelaksanaan Program Imunisasi COVID-19 Kebangsaan melalui penyediaan vaksin daripada jenis mRNA (Pfizer), Vektor Virus (AstraZeneca, CanSinoBio, S-Putnik V) dan Virus nyahaktif (Sinovac) (Jawatankuasa Khas Jaminan Akses Bekalan Vaksin Covid-19, 2021). Tujuan utamanya adalah untuk mengekang penularan pandemik COVID-19 daripada terus berlaku diperingkat dalam negara. Schuchat (2011) menjelaskan bahawa program imunisasi atau vaksinasi adalah penting untuk menjamin kesihatan dan kesejahteraan manusia sejagat. Menurutnya lagi, manfaat kumulatif daripada programvaksinasi sangat besar khususnya daripada aspek kesihatan awam. Ini kerana, selain mampu memanjangkan jangka hayat manusia, vaksinasi juga mampu melenyapkan wabak penyakit seterusnya membebaskan ketakutan ibu-bapa berhubung ancaman penyakit terhadap kanak-kanak. Perkara ini dibuktikan apabila penyakit yang dapat dicegah oleh vaksin telah banyak dikurangkan melalui rutin program suntikan di negara maju (Hamid, 2019).

Walaupun begitu, pelaksanaan Program Imunisasi COVID-19 Kebangsaan didapati kurang mendapat sambutan seperti yang diharapkan oleh pihak kerajaan Malaysia. Ini kerana, berlakunya isu penolakan terhadap vaksin oleh sebahagian masyarakat di Malaysia (Rumettta et al., 2020) khususnya yang bersangkutan dengan vaksin pandemik COVID-19 (BH Online, 2021). Khairy Jamaluddin Abu bakar yang menyandang jawatan Menteri Sains, Teknologi dan Inovasi menjelaskan bahawa jumlah pendaftaran vaksin dalam kalangan rakyat Malaysia sehingga bulan Mac 2021 adalah masih rendah iaitu hanya sekitar 6.1 peratus. Menurutnya lagi, jumlah peratusan tersebut masih lagi jauh daripada sasaran pihak kerajaan (Ridauddin Daud, 2021). Perkara yang lebih mendukacitakan apabila kadar pendaftaran penerima vaksin COVID-19 menjadi semakin perlahan (Ahmad Suhael Adnan, 2021). Keadaan ini sudah tentu menyukarkan pihak kerajaan untuk mencapai sasarannya iaitu melakukan vaksinasi kepada 80 peratus atau 23.6 juta penduduk Malaysia menjelang bulan Februari tahun 2022 (JKJAV, 2021; The Strait Times, 2021). Apatah lagi dianggarkan sekurang-kurangnya 55 peratus daripada jumlah populasi di satu-satu kawasan harus menerima vaksin sekiranya ingin mencapai tahap kekebalan (herd immunity) setinggi 85 peratus (Kwok et al., 2020). Pengurangan terhadap jumlah pendaftaran vaksin diperingkat negara secara tidak langsung dipengaruhi oleh sikap masyarakat Malaysia Timur (Sabah). Ini kerana, berbanding dua belas buah negeri lain yang terdapat di Malaysia, negeri Sabah mencatatkan nilai terendah sebagai pendaftar penerima vaksin (Durie Rainer Fong, 2021).

Penolakan vaksin dalam skala yang besar akan mendatangkan kesan negatif daripada pelbagai aspek. Salah satunya akan mengurangkan kekebalan kelompok masyarakat (community herd immunity) dalam berhadapan dengan penyebaran wabak (Salathé, M. \& Bonhoeffer, 2008). Kesan berantai daripada penyebaran wabak secara berterusan pula akan meningkatkan kos rawatan pesakit di pusat kesihatan (Kaye et al., 2020). Selain itu, Perintah Kawalan Pergerakan (PKP) juga sukar untuk ditamatkan sekiranya program vaksinasi tidak mendapat sambutan memuaskan berikutan kurangnya mekanisme lain yang lebih efektif dalam mencegah penularan pandemik COVID-19. Malangnya, pelaksanaan PKP secara berterusan dalam tempoh yang panjang sudah tentu akan mendatangkan masalah lain seperti terjadinya kes pengangguran berskala besar (Estro Dariatno Sihaloho, 2020), 
DOI: https://doi.org/10.47405/mjssh.v6i7.859

pengurangan jumlah pendapatan (Jabatan Perangkaan Malaysia, 2020), menyebabkan stress, kemurungan (Ghani, 2020) dan lain-lain lagi. Oleh itu, kajian ini bertujuan untuk mengenalpasti tahap keberkesanan Program Vaksinisasi COVID-19 di Sabah. Dalam masa yang sama kajian ini turut membincangkan mengenai faktor penolak dan penarik yang mempengaruhi kepada keberhasilan program ini.

\section{Metod Kajian}

Reka bentuk kajian ini menggunakan pendekatan kuantitatif. Oleh hal demikian, kaedah survei digunakan dalam proses pengutipan data di lapangan. Responden yang ditemubual adalah dalam kalangan penduduk di Sabah (Malaysia Timur) iaitu seramai 1024 orang. Sampel ditentukan berdasarkan teknik persampelan rawak mudah. Jumlah populasi penduduk di Sabah pada tahun 2021 adalah seramai 3,904,500 orang (Jabatan Perangkaan Malaysia, 2021). Menurut Yamane (1967) berdasarkan pengiraan melalui formulanya mendapati minimumnya seramai 400 sampel diperlukan bagi mewakili jumlah populasi seramai 3,904,500 orang. Ini bermakna, jumlah sampel yang digunakan dalam kajian ini iaitu seramai 1024 orang adalah memadai bagi mewakili populasi kajian. Sampel kajian ini dikutip menggunakan dua cara iaitu secara dalam talian menggunakan google form (Whatsapp \& Facebook) dan melalui edaran borang soal selidik di lapangan. Hal ini sebagai langkah keselamatan untuk meminimumkan berlakunya perebakan jangkitan Covid-19. Proses pengutipan data melalui edaran google form dan soal selidik dijalankan secara bersamaan selama lebih kurang dua minggu iaitu bermula pada 30 Mac 2021 hingga 15 April 2021. Sampel kajian ini mewakili keseluruhan zon di Sabah iaitu Zon Barat laut (21.9\%), Zon Barat Daya (13.7\%), Zon Pedalaman (17.6\%), Zon Barat Tengah (28.1\%), Zon Timur Laut (9.2\%) dan Zon Tenggara (9.6\%). Soalan yang ditanyakan kepada responden berbentuk skala likert dengan lima pilihan jawapan iaitu ' $1=$ sangat tidak setuju, ' $2=$ tidak setuju, ' $3=$ kurang setuju, ' $4=$ setuju dan ' $5=$ sangat setuju.

Data mentah yang diperolehi melalui instrumen soal selidik seterusnya dianalisis secara frekuensi dan menggunakan skor min. Analisis skor min bertujuan untuk mengukur tahap keberkesanan Program Vaksinisasi COVID-19 Kebangsaan. Untuk memudahkan pentafsiran data dilakukan, skor min dikelompokkan menjadi tiga kategori iaitu rendah (1.00-2.33), sederhana (2.34-3.67), tinggi (3.685.00) (Abdullah et al., 2017; Noorazuan Md Hashim \& Shamsuddin, 2018). Konstruk pemboleh-ubah yang digunakan dalam kajian ini merangkumi aspek komunikasi, keselamatan, psikologi dan persekitaran (rujuk Jadual 1). Kajian ini menggunakan 21 pemboleh-ubah bagi mewakili konstrukkonstruk tersebut. Pembentukan soalan atau pemboleh-ubah yang digunakan dalam kajian ini diadaptasi daripada Fauzi et al. (2016), Fauzi et al. (2018), Rumetta et al. (2020) dan Salam (2021).

Jadual 1: Pemboleh-ubah yang digunakan untuk mengukur tahap keberkesanan Program Imunisasi COVID-19 Kebangsaan

\begin{tabular}{ll}
\hline Konstruk & Pembolehubah \\
\hline \multirow{5}{*}{ Keselamatan } & Ke1) Yakin dengan kehalalan vaksin. \\
& Ke2) Vaksin selamat untuk tubuh badan saya. \\
& Ke3) Vaksin lebih selamat \& berkesan berbanding kaedah alternatif lain. \\
& Ke4) Vaksin sedia ada sekarang ini sudah memadai untuk digunakan. \\
& Ke5) Yakin vaksin mampu mencegah penularan Covid-19 \\
& Ko1) Maklumat berkaitan Program Imunisasi COVID-19 di media perdana \\
& mudah diperolehi. \\
Ko2) Maklumat berkaitan vaksin di media perdana mudah diperolehi. \\
Ko3) Maklumat berkaitan vaksin di media arus perdana boleh dipercayai. \\
Ko4) Isu viral berkaitan vaksin tidak mempengaruhi saya untuk tidak \\
mengambil vaksin. \\
Ko5) Saya tidak mengalami masalah internet untuk mendaftar PICK. \\
Ko6) Proses pendaftaran Program Imunisasi COVID-19 Kebangsaan sangat \\
mudah. \\
Ps1) Saya tidak takut untuk disuntik.
\end{tabular}




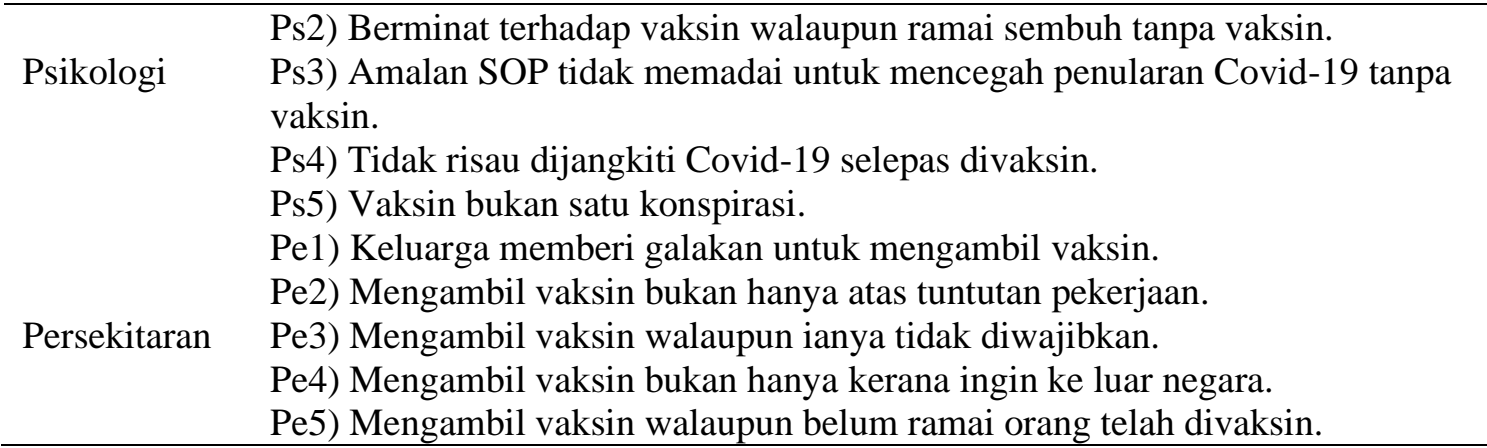

Kajian ini dijalankan di Sabah iaitu sebuah negeri yang terletak di bahagian Timur Malaysia (rujuk Rajah 1). Negeri ini mempunyai saiz keluasan sekitar 74,000 km persegi sekaligus merupakan negeri kedua terbesar di Malaysia (Suruhanjaya Pilihan Raya Malaysia, 2017). Negeri Sabah terbentuk daripada gabungan enam buah zon merangkumi Zon Barat Daya, Zon Barat Laut, Zon Barat Tengah, Zon Pedalaman, Zon Tenggara dan Zon Timur Laut. Keenam-enam zon ini pula terbentuk daripada gabungan 25 buah daerah merangkumi Daerah Kota Kinabalu, Tawau, Sandakan, Lahad Datu, Keningau, Kinabatangan, Semporna, Papar, Penampang, Beluran, Tuaran, Ranau, Belud, Kudat, Beaufort, Kota Marudu, Kunak, Putatan, Tenom, Pitas, Sipitang, Tongod, Tambunan, Nabawan dan Kuala Penyu (Jabatan Perangkaan Malaysia, 2019).

Rajah 1: Kedudukan Sabah yang terletak di Bahagian Timur Malaysia

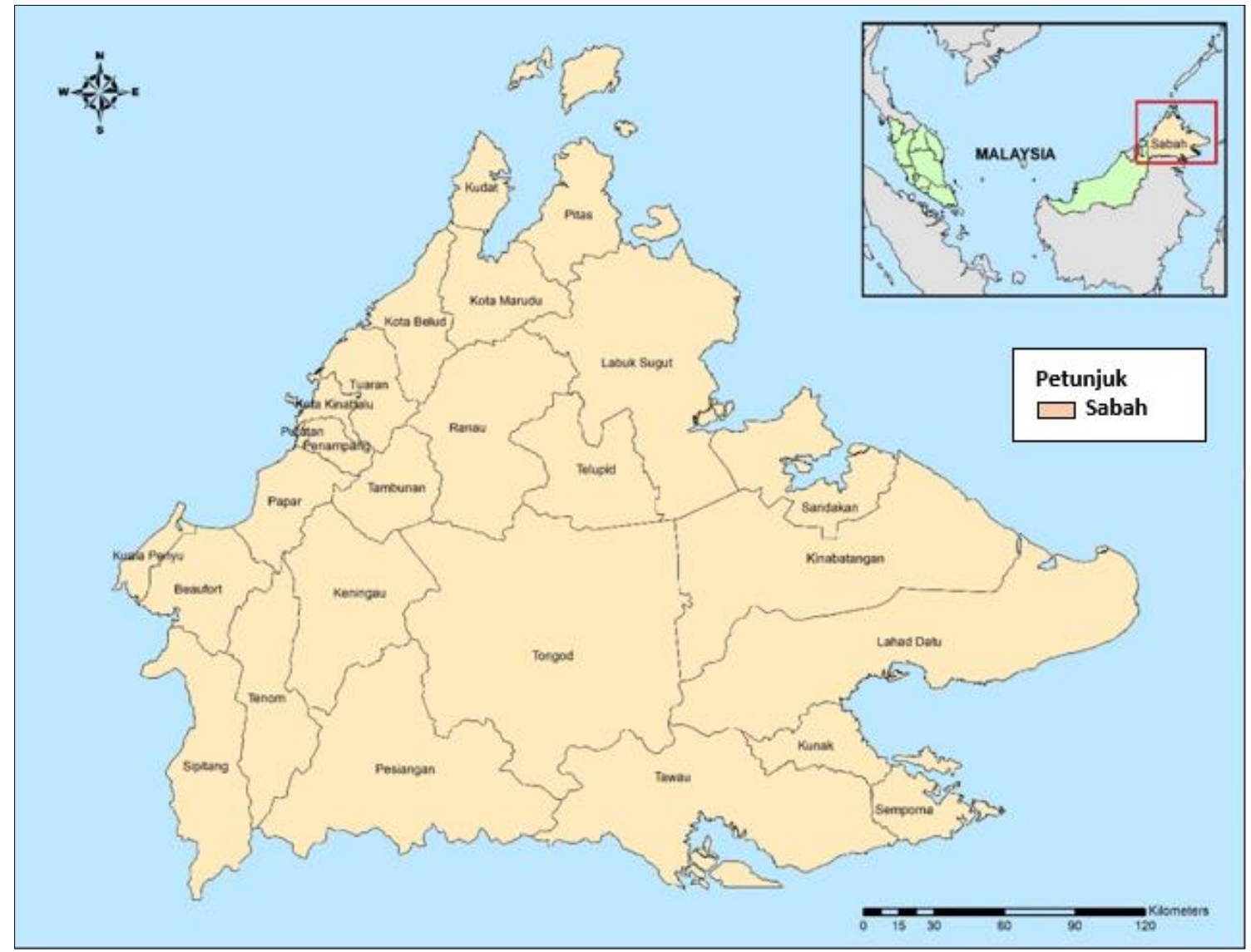

Sumber: Diubahsuai daripada Jabatan Perancang Bandar dan Wilayah Sabah (2021) 


\section{Dapatan Kajian}

\section{Ciri-ciri Demografi Responden}

Melalui analisis yang dilakukan mendapati hampir separuh (kekerapan=595 orang, peratus=58.1\%) daripada jumlah keseluruhan responden dalam kajian ini telah mendaftar untuk divaksin. Selain itu, sebahagian besar (kekerapan $=814$ orang, peratus $=79.5 \%$ ) responden kajian ini terdiri daripada golongan muda yang berumur 18 hingga 40 tahun. Selebihnya lagi iaitu masing-masing sebanyak 182 orang $(17.8 \%)$ dan 28 orang (2.7\%) terdiri daripada kelompok dewasa dan orang tua. Dalam kajian ini, golongan wanita didapati lebih ramai (Kekerapan=551 orang, peratus $=53.8 \%$ ) berbanding golongan lelaki (kekerapan $=473$ orang, peratus $=46.2 \%$ ). Daripada aspek status perkahwinan pula, rata-rata responden dalam kajian ini berstatus bujang (kekerapan $=592$ orang, peratus $=57.8 \%$ ). Responden dalam kajian ini juga dominannya adalah golongan pelajar (kekerapan=269 orang, peratus=26.3\%) dan staf kerajaan (kekerapan=248 orang, peratus $=24.1 \%$ ). Namun demikian, sebahagiannya juga terdiri daripada pekerja swasta (Kekerapan $=210$ orang, peratus $=20.5 \%$ ), golongan peniaga (Kekerapan $=171$ orang, peratus $=16.7 \%$ ), golongan tidak bekerja (kekerapan=63 orang, peratus $=6.2 \%$ ), golongan pesara (kekerapan $=16$ orang, peratus $=1.6 \%$ ) dan golongan suri rumah (kekerapan $=47$ orang, peratus $=4.6 \%$ ). Lebih separuh (Kekerapan $=625$ orang, Peratus $=61 \%$ ) daripada keseluruhan responden kajian ini beragama Islam. Para responden juga kebanyakannya adalah berbangsa KDMR (kekerapan $=410$ orang, peratus $=40 \%$ ) dan berpendidikan tinggi hingga ke peringkat universiti (kekerapan $=646$, peratus $=63.1 \%$ ). Daripada status ekonomi, sebahagian besar daripada sampel kajian terdiri daripada golongan B40 (kekerapan $=854$ orang, peratus $=83.4 \%$ ).

\section{Jadual 2: Ciri-Ciri Sosiodemografi Responden}

\begin{tabular}{|c|c|}
\hline Ciri Demografi & Statistik \\
\hline \multirow[t]{2}{*}{ Status Pendaftaran } & Telah mendaftar $(58.1 \%)$ \\
\hline & Belum mendaftar (41.9\%) \\
\hline \multirow[t]{2}{*}{ Jantina } & Lelaki $(46.2 \%)$ \\
\hline & Perempuan $(53.8 \%)$ \\
\hline Status & Berkahwin $(42.2 \%)$ \\
\hline Perkahwinan & Belum berkahwin $(57.8 \%)$ \\
\hline \multirow[t]{3}{*}{ Umur } & $18-40$ tahun $(79.5 \%)$ \\
\hline & $41-60$ tahun $(17.8 \%)$ \\
\hline & $61 \&$ ke atas $(2.7 \%)$ \\
\hline \multirow[t]{7}{*}{ Jenis Pekerjaan } & Sektor Kerajaan (24.1\%) \\
\hline & Sektor Swasta (20.5\%) \\
\hline & Bekerja Sendiri (16.7\%) \\
\hline & Tidak Bekerja (6.2\%) \\
\hline & Pesara $(1.6 \%)$ \\
\hline & Suri Rumah (4.6\%) \\
\hline & Pelajar $(26.3 \%)$ \\
\hline \multirow[t]{3}{*}{ Agama } & Islam (61\%) \\
\hline & Kristian (37.9\%) \\
\hline & Agama lain-lain (1.1\%) \\
\hline \multirow[t]{5}{*}{ Etnik } & KDMR (40\%) \\
\hline & Bajau (14.3\%) \\
\hline & Bugis (12.5\%) \\
\hline & Melayu Brunei (7.2\%) \\
\hline & Suluk $(3.5 \%)$ \\
\hline
\end{tabular}




\begin{tabular}{ll}
\hline & Cina $(2.4 \%)$ \\
& India $(0.2 \%)$ \\
& suku kaum lain $(19.8 \%)$ \\
& \\
Tahap Pendidikan & Tidak Bersekolah $(2.6 \%)$ \\
& Sekolah Rendah $(2.9 \%)$ \\
& Sekolah Menengah $(31.3 \%)$ \\
& Kolej/Universiti $(63.1 \%)$ \\
& \\
Jumlah & B40(83.4\%) \\
Pendapatan & M40 $(13.6 \%)$ \\
& T20 $(3 \%)$ \\
\hline
\end{tabular}

Kajian ini mendapati tahap keberkesanan Program Imunisasi COVID-19 Kebangsaan di Sabah secara keseluruhannya adalah pada tahap yang sederhana $(\mathrm{M}=3.37, \mathrm{SP}=.468)$. Hal ini berpunca daripada isu persekitaran $(\mathrm{M}=3.02, \mathrm{SP}=.745)$. Ini kerana, kebanyakan responden tidak menerima galakan daripada keluarga untuk mengambil vaksin $(\mathrm{M}=2.56, \mathrm{SP}=1.23)$. Selain itu, tindakan kerajaan untuk tidak mewajibkan pengambilan vaksin juga menjadi faktor penting dalam merencatkan kelancaran program ini $(\mathrm{M}=2.96, \mathrm{SP}=1.282)$. Kebanyakan daripada responden masih berasa was-was untuk mengambil vaksin atas alasan menunggu orang lain divaksin terlebih dahulu $(\mathrm{M}=2.99, \mathrm{SP}=1.253)$. Berdasarkan analisis kajian ini juga mendapati aspek komunikasi $(\mathrm{M}=3.25, \mathrm{SP}=.681)$ memainkan peranan penting dalam memastikan keberkesanan program ini. Hal ini disebabkan, sebahagian daripada responden sukar mempercayai maklumat berkaitan vaksin yang bersumberkan media arus perdana $(\mathrm{M}=2.87$, $\mathrm{SP}=1.22)$. Mereka juga berpendapat maklumat berkaitan vaksin $(\mathrm{M}=2.67, \mathrm{SP}=1.171)$ dan Program Imunisasi COVID-19 Kebangsaan sukar diperolehi $(\mathrm{M}=2.88, \mathrm{SP}=1.189)$. Walau bagaimanapun, sebahagian besar daripada responden beranggapan proses pendaftaran Program Imunisasi COVID-19 Kebangsaan sangat mudah dilakukan ( $\mathrm{M}=4.07, \mathrm{SP}=.806)$.

Daripada aspek psikologinya pula, sebahagian responden merasakan amalan SOP sudah memadai untuk mencegah penularan Covid-19 tanpa vaksin $(\mathrm{M}=3.18, \mathrm{SP}=1.298)$ dan tidak berminat untuk mengambil vaksin disebabkan ramai orang sembuh tanpa vaksin $(\mathrm{M}=3.39, \mathrm{SP}=1.258)$. Walaupun begitu daripada sisi positifnya, sebahagian besar responden mempercayai vaksin bukan satu konspirasi $(\mathrm{M}=3.76, \mathrm{SP}=1.126)$ dan berasa tidak risau dijangkiti Covid-19 selepas divaksin $(\mathrm{M}=3.75, \mathrm{SP}=.980)$. Uniknya dalam konteks negeri Sabah, aspek keselamatan bukanlah isu utama yang perlu dibimbangkan $(\mathrm{M}=3.69, \mathrm{SP}=.584)$. Hal ini kerana, rata-rata responden yakin dengan kehalalan vaksin $(\mathrm{M}=4.01, \mathrm{SP}=.838)$. Mereka juga percaya vaksin mampu mencegah penularan Covid-19 $(\mathrm{M}=3.94$, $\mathrm{SP}=.809)$ dan tidak memudaratkan kesihatan tubuh badan $(\mathrm{M}=3.76, \mathrm{SP}=.915)$. Namun demikian, sebahagian besar responden juga tidak menolak bahawa terdapat kaedah alternatif lain yang lebih berkesan dan selamat berbanding vaksin ( $\mathrm{M}=2.99, \mathrm{SP}=1.233)$ (rujuk Jadual 3).

Jadual 3: Tahap Keberkesanan Program Imunisasi COVID-19 Kebangsaan Di Sabah

\begin{tabular}{lllllll}
\hline Aspek & kod & $\begin{array}{l}\text { Man } \\
(\mathbf{M})\end{array}$ & $\begin{array}{l}\text { Sisihan } \\
\text { Piawai (SP) }\end{array}$ & $\begin{array}{l}\text { Min } \\
(\mathbf{M})\end{array}$ & $\begin{array}{l}\text { Sisihan } \\
\text { Piawai (SP) }\end{array}$ & Tahap \\
\cline { 2 - 4 } Keselamatan & Ke1 & 4.01 & .838 & & & \\
& ke2 & 3.76 & .915 & & & \\
& ke3 & 2.99 & 1.233 & 3.69 & .584 & Tinggi \\
& ke4 & 3.72 & .982 & & & \\
& ke5 & 3.94 & .809 & & & \\
Komunikasi & ko1 & 2.88 & 1.189 & & & \\
& ko2 & 2.67 & 1.171 & & & \\
& ko3 & 2.87 & 1.220 & & & \\
& ko4 & 3.39 & 1.248 & 3.25 & .681 & \\
& ko5 & 3.61 & 1.147 & & & \\
& ko6 & 4.07 & .806 & & & \\
& Ps1 & 3.68 & 1.225 & & & \\
& & & & www.msocialsciences.com & &
\end{tabular}


DOI: https://doi.org/10.47405/mjssh.v6i7.859

\begin{tabular}{lllllll}
\multirow{7}{*}{ Psikologi } & Ps2 & 3.39 & 1.258 & & & \\
& Ps3 & 3.18 & 1.298 & 3.55 & .843 & Sederhana \\
& Ps4 & 3.75 & .980 & & & \\
& Ps5 & 3.76 & 1.126 & & & \\
& Pe1 & 2.56 & 1.230 & & & \\
& Pe2 & 3.14 & 1.261 & & & \\
\hline \multirow{5}{*}{ Kersekitaran } & Pe3 & 2.96 & 1.282 & 3.02 & .745 & Sederhana \\
& Pe4 & 3.46 & 1.263 & & & \\
\hline
\end{tabular}

\section{Indeks Petunjuk Keberkesanan Program Imunisasi COVID-19 Kebangsaan di Sabah}

Indeks petunjuk keberkesanan Program Imunisasi COVID-19 Kebangsaan diukur berdasarkan formula yang ditunjukkan pada Rajah 2. Jumlah skor min elemen atau item yang bernilai 70.78 dibahagikan dengan hasil darab antara jumlah konstruk item (21) dengan aras tertinggi skala likert yang digunakan (5). Hasil daripada pengiraan tersebut seterusnya didarab dengan 100. Kaedah ini digunakan oleh beberapa orang sarjana untuk mengukur keberkesanan satu-satu program. Noor et al. (2016) misalnya menggunakan formula ini untuk mengukur keberkesanan perkhidmatan bas mini di Kota Kinabalu manakala Azmizam (2011) pula mengaplikasikannya untuk mengukur keberkesanan pentadbiran pihak berkuasa tempatan. Selain itu, formula ini juga didapati boleh digunakan untuk mengukur tahap kepuasan pengguna dalam perkhidmatan (Hayes, 1999). Hasil keputusan Indeks Petunjuk Keberkesanan Program Imunisasi COVID-19 Kebangsaan di Sabah didapati berada pada tahap 66.67 peratus.

Rajah 2: Indeks Petunjuk Keberkesanan Program Imunisasi COVID-19 Kebangsaan di Sabah

$$
\begin{aligned}
& =\left(\frac{\text { Jumlah skor } \text { min } \text { elemen keberkesanan }}{\text { Jumlah konstruk elemen } \times \text { Aras tertinggi keberkesanan }}\right) \times 100 \\
& =\left(\frac{70.78}{21 \times 5}\right) \times 100 \\
& =\left(\frac{70.78}{105}\right) \times 100 \\
& =66.67 \%
\end{aligned}
$$

\section{Perbincangan}

Secara umumnya, kajian ini mendapati tahap Keberkesanan Program Imunisasi COVID-19 Kebangsaan di Sabah adalah pada tahap sederhana dengan nilai indeks petunjuk keberkesanan sebanyak 66.67 peratus. Melalui analisis kajian ini juga mendapati terdapat beberapa faktor yang menjadi halangan kepada rakyat Sabah untuk menyertai Program Imunisasi COVID-19 Kebangsaan. Maklumat berkaitan vaksin dan Program Imunisasi COVID-19 Kebangsaan yang sukar diperoleh di media arus perdana merupakan antara penyebab utama kepada ketidaklancaran program terbabit. Selain itu, ketidakpercayaan terhadap maklumat berkaitan vaksin di media arus perdana juga merupakan faktor utama kepada tercetusnya situasi ini. Hal ini menunjukkan bahawa aspek komunikasi atau pengaruh media massa merupakan antara faktor penting dalam menentukan keberkesanan satu-satu program khususnya Program Imunisasi COVID-19 Kebangsaan. Dalam masa yang sama, melalui dapatan ini secara tidak langsung juga menunjukkan bahawa wujudnya kelemahan 
media perdana sebagai medium berautoriti untuk menyampaikan maklumat sahih kepada rakyat berhubung dengan Program Imunisasi COVID-19 Kebangsaan secara lebih berkesan. Perkara ini amat mustahak untuk ditambah baik memandangkan media massa memberi pengaruh yang sangat besar terhadap literasi dan reaksi masyarakat khususnya berhubung dengan program vaksinasi (Ohorella et al., 2018), COVID-19 (Rzymski, 2021).

Selain itu, sikap rakyat Sabah yang sebahagiannya mudah terpengaruh dengan isu viral berkaitan vaksin di media sosial meruncingkan lagi keadaan ini. Dapatan kajian ini bukanlah suatu yang mengejutkan memandangkan sebahagian besar sampel kajian ini terdiri daripada golongan muda. Hal ini terjadi berikutan keterdedahan golongan muda adalah semakin tinggi ke atas penggunaan media sosial untuk tujuan berkomunikasi dan mencari sumber maklumat (Manap et al., 2016; Sannusi et al., 2019). Walhal, menurut Fauzi (2017) media sosial tidak hanya memberikan kesan positif terhadap golongan muda bahkan dalam masa yang sama turut mempunyai sisi negatifnya yang tersendiri. Ini kerana, dengan melayari media sosial golongan muda semakin terdedah kepada fitnah, penipuan (Manap et al., 2016) dan berita palsu (Ohorella et al., 2018; Johnson, 2020). Keadaan ini akhirnya boleh membawa kepada masalah lain seperti mewujudkan keraguan terhadap penggunaan vaksin (vaccine hesitancy) (Johnson, 2020). Isu berkenaan keraguan vaksin yang berpunca daripada sebaran maklumat palsu di media sosial bukanlah isu lokal, bahkan ianya merupakan isu sejagat yang juga berlaku di negara lain (Rzymski, 2021). Bahkan, Vaccine hesitancy telah dilabelkan oleh World Health Organization (WHO) sebagai salah satu daripada 10 ancaman kesihatan global (Alias, 2020).

Informasi palsu yang diterima daripada media sosial lazimnya menambahkan ketakutan masyarakat untuk menggunakan vaksin atas faktor keselamatan (Geldsetzer et al., 2020). Justeru itu, tidak menghairankan apabila ramai yang beranggapan bahawa terdapat kaedah alternatif lain yang lebih selamat dan berkesan berbanding penggunaan vaksin $(\mathrm{M}=2.99, \mathrm{SP}=1.233)$. Perkara ini akhirnya membentuk persekitaran yang tidak sihat apabila masyarakat mula berpendapat bahawa hanya akan mengambil vaksin setelah ramai orang telah divaksin dan sehinggalah ia diwajibkan. Perkara yang lebih mendukacitakan apabila tindakan kebanyakan keluarga yang tidak mendorong atau menggalakkan pengambilan vaksin atas faktor berlakunya vaccine hesitancy. Masalah yang sama juga berlaku di beberapa buah negara lain seperti di Rusia (Lazarus, 2021), Republic of the Congo (Nzaji et al., 2020) dan di Los Angeles, Amerika Syarikat (Gadoth et al., 2020) apabila sebahagian rakyatnya didapati ragu-ragu untuk mengambil vaksin. Selain itu, berdasarkan laporan yang dikeluarkan oleh Our World in Data (2021) mendapati hampir separuh daripada keseluruhan penduduk di Perancis dan Korea Selatan sehingga April 2021 masih belum divaksin. Dalam kelompok tersebut, sebahagiannya berasa was-was untuk divaksin dan sebahagiannya lagi tidak mahu divaksin.

Walaupun begitu daripada sisi positif lainnya, terdapat juga beberapa faktor penarik yang menyumbang kepada keberhasilan program ini. Berdasarkan analisis yang dilakukan mendapati ratarata responden bersetuju bahawa proses pendaftaran Program Imunisasi COVID-19 Kebangsaan sangat mudah dilakukan $(\mathrm{M}=4.07, \mathrm{SP}=.806)$. Hal ini berpunca daripada wujudnya sistem pendaftaran bersifat sistematik dan mesra pengguna yang telah dibangunkan oleh pihak pemegang taruh atau pihak berautoriti. Terdapat beberapa cara atau kaedah pendaftaran yang disediakan untuk tujuan mendaftar vaksin iaitu menerusi aplikasi MySejahtera, melalui talian hotline, menerusi laman sesawang www.vaksincovid.gov.my, pendaftaran di fasiliti kesihatan kerajaan dan swasta serta melalui program bantuan (outreach) bagi kawasan luar bandar dan pedalaman (JKJAV, 2021).

Kajian ini juga mendapati kebanyakan responden begitu yakin bahawa vaksin yang disediakan oleh pihak berautoriti adalah halal untuk digunakan. Pihak Pejabat Mufti Wilayah Persekutuan (PMWP) pada 11 Februari 2021 menetapkan hukum penggunaan vaksin COVID-19 dalam kalangan masyarakat Islam, khususnya di Wilayah Persekutuan adalah harus dan wajib diambil (Rafidah, 2021). Kenyataan ini diyakini membantu mengurangkan kekeliruan masyarakat terutamanya kepada golongan beragama Islam berhubung dengan isu kehalalan vaksin COVID-19. Perkara ini sangat penting untuk dititikberatkan memandangkan lebih separuh (61.3\%) daripada rakyat Malaysia adalah beragama Islam dan sangat cakna terhadap isu kehalalan vaksin (Khoo et al., 2020). Keraguan yang tinggi terhadap kehalalan vaksin akibat penyebaran maklumat palsu berpotensi menyebabkan berlakunya kegagalan program vaksinasi sama ada di peringkat dalam mahupun luar negara (Ahmed et al., 2018). 


\section{Kesimpulan}

Kesimpulannya, kajian ini mendapati tahap Keberkesanan Program Imunisasi COVID-19 Kebangsaan di Malaysia Timur (Sabah) adalah pada tahap sederhana dengan nilai indeks petunjuk keberkesanan sebanyak 66.67 peratus. Dalam masa yang sama, analisis kajian ini juga berjaya mengenal pasti faktorfaktor yang mempengaruhi keberkesanan program tersebut. Maklumat berkaitan vaksin dan Program Imunisasi COVID-19 Kebangsaan yang sukar diperoleh di media arus perdana merupakan antara penyebab utama yang mengganggu ketidaklancaran program tersebut. Selain itu, ketidakpercayaan terhadap maklumat berkaitan vaksin di media arus perdana dan Sikap rakyat Sabah yang sebahagiannya mudah terpengaruh dengan Isu viral berkaitan vaksin di media sosial juga menyumbang kepada ketidaklancaran program terbabit. Walaupun begitu, terdapat juga beberapa faktor yang menjadikan masyarakat Sabah tertarik menyertai program ini. Kebanyakan responden bersetuju bahawa proses pendaftaran Program Imunisasi COVID-19 Kebangsaan sangat mudah dilakukan. Majoriti responden juga begitu yakin bahawa vaksin yang disediakan oleh pihak berautoriti adalah halal untuk digunakan. Situasi ini menjelaskan bahawa terdapat beberapa perkara yang harus ditambah baik bagi memantapkan dan memperkasakan lagi pelaksanaan PICK. Sehubungan dengan itu, dapatan kajian ini diharap dapat dijadikan sumber maklumat sokongan bagi membantu pihak yang bersangkutan untuk meningkatkan keberkesanan PICK ke arah yang lebih baik.

\section{Rujukan}

Abdullah, A. H., Rahman, S. N. S. A., \& Hamzah, M. H. (2017). Metacognitive skills of Malaysian students in non-routine mathematical problem solving. Bolema-Mathematics Education Bulletin, 31(57), 310-322. https://doi.org/10.1590/1980-4415v31n57a15.

Ahmad Suhael Adnan. (21 Mac 2021). Pendaftaran penerima vaksin COVID-19 semakin perlahan. Diakses daripada https://www.bharian.com.my/berita/nasional/2021/03/798592/pendaftaranpenerima-vaksin-covid-19-semakin-perlahan pada 20 Mei 2021.

Ahmed, A., Lee, K. S., Bukhsh, A., Al-Worafi, Y. M., Sarker, M. M. R., Ming, L. C., \& Khan, T. M. (2018). Outbreak of vaccine-preventable diseases in Muslim majority countries. Journal of infection and public health, 11(2), 153-155.

Alcántara-Ayala, I., Burton, I., Lavell, A., Mansilla, E., Maskrey, A., Oliver-Smith, A., \& RamírezGómez, F. (2021). Root causes and policy dilemmas of the COVID-19 pandemic global disaster. International Journal of Disaster Risk Reduction, 52, 101892.

Alias, C. D. M. F. (2020). Health And Security: An Analysis Of Vaccine Hesitancy In Malaysia. The Journal of Defence and Security, 12(1), 1-I.

Azmizam, A., R. (2011). Keefisienan Governan Bandar dalam Meningkatkan Daya Persaingan Ekonomi Wilayah-Bandar Raya Kuala Lumpur dari Perpekstif Pihak-Pihak Berkepentingan. Unpublished PhD Thesis, Universiti Kebangsaan Malaysia.

BH Online. (15 February 2021). Tolak vaksin nafi hak rakyat bebas wabak. Diakses daripada https://www.bharian.com.my/rencana/minda-pembaca/2021/02/786288/tolak-vaksin- nafi-hakrakyat- bebas-wabak pada 21 Mei 2021.

Durie Rainer Fong. (26 March 2021). Sabah's low vaccine registration number worries state rep. Diakses daripada

https://www.freemalaysiatoday.com/category/nation/2021/03/26/sabahs-low- vaccineregistration-number-worries-state-rep/ pada 20 May 2021.

Estro Dariatno Sihaloho. (2020). Dampak Covid-19 Terhadap Perekonomian Indonesia.https://www.researchgate.net/publication/340554267.

Fauzi, N. (2017). Penggunaan media sosial dalam dunia tanpa sempadan: Suatu kebaikan atau keburukan. Institut Latihan Kehakiman dan Perundangan.

Fauzi, T. F. A. T. M., Razif, N. F. M., \& Ramli, M. A. (2018). Polemics between Acceptance and Rejection of Children's Vaccination: An Analysis from Islamic Perspective. Shariah J, 26(2), 201-230.

Fauzi, T. F. A. T. M., Ramli, M. A., \& Sharifuddin, N. M. (2016). Vaksinasi terhadap Kanak-Kanak Menurut Perspektif Maqasid Syariah. Maqasid al-Shariah. Aplikasi Dalam Aspek Sains \& Teknologi, 75-100. 
Gadoth, A.; Halbrook, M.; Martin-Blais, R.; Gray, A.; Tobin, N.H.; Ferbas, K.G.; Aldrovandi, G.M.; Rimoin, A.W. (2020). Assessment of COVID-19 vaccine acceptance among healthcare workers in Los Angeles. medRxiv.

Geldsetzer, P. (2020). Knowledge and perceptions of COVID-19 among the general public in the United States and the United Kingdom: a cross-sectional online survey. Annals of internal medicine, 173(2), 157-160.

Ghani, F. A. (2020). Impak psikologi akibat wabak Covid-19, Astro Awani, 14 Mac 2020. Dipetik dari http://www.astroawani.com/beritamalaysia/ impak-psikologi-akibat-wabakcovid-19-233648 pada 23 Ogos 2020.

Hamid, S. A. (2019). Anti Vaksin: Apakah Natijahnya Kepada Masyarakat?. E-Bangi, 16(2).

Hayes, B. E. (1998). Measuring customer satisfaction: Survey design, use, and statistical analysis methods. Milwaukee^ eWisconsin Wisconsin: ASQC Quality Press.

Jabatan Perangkaan Malaysia. (2021). Banci Penduduk dan Perumahan Malaysia. Diakses daripada https://www.mycensus.gov.my/index.php/ms/125-newsletter-infographics/1646-scdp-sabah pada 20 Mei 2021.

Jabatan Perangkaan Malaysia. (2020). Newsletter. Diakses daripada www.dosm.gov.my pada 20 Mei 2020.

Jabatan Perangkaan Malaysia. (2019). Laporan Sosioekonomi Negeri Sabah 2019. Diakses dari https://www.dosm.gov.my/v1/uploads/files/1_Articles_By_Themes/National\%20Accounts/GDPb yState/2020/Laporan_Sosioekonomi_Sabah_2019.pdf pada 10 Jun 2021.

Jabatan Perancang Bandar dan Wilayah Sabah. (2021). Peta Daerah Sabah.

Jafar, A., Geogre, F., Mapa, M. T., Sakke, N., \& Dollah, R. (2021). Perceptions Of Urban Poor With B40 Status On The Impact Of The Implementation Of Movement Control Order (Mco) By Employment Sector: A Case Study Of Kota Kinabalu City, Sabah. Journal Of Contemporary Issues In Business And Government, 27(2), 3603-3618.

Jawatankuasa Khas Jaminan Akses Bekalan Vaksin COVID-19 (JKJAV). (2021). Program Imunisasi COVID-19 Kebangsaan: Lindungi Diri, Lindungi Semua. Diakses daripada https://www.vaksincovid.gov.my/pdf/Program_Imunisasi_COVID19_Kebangsaan_Versi_Bahasa Malaysia.pdf pada 20 Mei 2021.

Johnson, N. F., Velásquez, N., Restrepo, N. J., Leahy, R., Gabriel, N., El Oud, S., ... \& Lupu, Y. (2020). The online competition between pro-and anti-vaccination views. Nature, 582(7811), 230233.

Kaye, A. D., Okeagu, C. N., Pham, A. D., Silva, R. A., Hurley, J. J., Arron, B. L., ... \& Cornett, E. M. (2020). Economic Impact of COVID-19 Pandemic on Health Care Facilities and Systems: International Perspectives. Best Practice \& Research Clinical Anaesthesiology.

Khoo, Y. S., Ghani, A. A., Navamukundan, A. A., Jahis, R., \& Gamil, A. (2020). Unique product quality considerations in vaccine development, registration and new program implementation in Malaysia. Human vaccines \& immunotherapeutics, 16(3), 530-538.

Kwok, K. O., Lai, F., Wei, W. I., Wong, S. Y. S. \& Tang, J. W. T. Herd immunity-estimating the level required to halt the COVID-19 epidemics in affected countries. J. Infect. 80, e32-e33 (2020).

Lazarus, J. V., Ratzan, S. C., Palayew, A., Gostin, L. O., Larson, H. J., Rabin, K., ... \& El-Mohandes, A. (2021). A global survey of potential acceptance of a COVID-19 vaccine. Nature medicine, 27(2), 225-228.

Manap, J., Hamzah, M. R., Amin, A. S., Izani, N. N. M., Idris, F., Hamjah, S. H., ... \& Saim, N. J. (2016, November). Penggunaan dan implikasi media sosial terhadap remaja generasi z. In International Conference on Social and Economic Development, 1-12.

Noor, H. M., Marzuki, M., Mapjabil, J., \& Eboy, O. V. (2016). Keberkesanan perkhidmatan bas mini di Kota Kinabalu Sabah (The effectiveness of the mini bus services in Kota Kinabalu, Sabah). Geografia-Malaysian Journal of Society and Space, 12.

Noorazuan Md Hashim \& Shamsuddin. (2018). Tanggapan, Kesedaran Dan Motivasi Masyarakat Terhadap Penggunaan Air Hujan Sebagai Bekalan Alternatif Bandar. GEOGRAFIA OnlineTM Malaysian Journal of Society and Space, 14(3), 37-52.

Nuryana, Z., \& Fauzi, N. A. F. (2020). The Fiqh of disaster: The mitigation of covid-19 in the perspective of Islamic education-neuroscience. International Journal of Disaster Risk Reduction, 51, 101848. 
Malaysian Journal of Social Sciences and Humanities (MJSSH), Volume 6, Issue 7, (page 1 - 11), 2021

DOI: https://doi.org/10.47405/mjssh.v6i7.859

Nzaji, M. K., Ngombe, L. K., Mwamba, G. N., Ndala, D. B. B., Miema, J. M., Lungoyo, C. L., ... \& Musenga, E. M. (2020). Acceptability of Vaccination Against COVID-19 Among Healthcare Workers in the Democratic Republic of the Congo. Pragmatic and observational research, 11, 103.

Ohorella, N. R., Putra, A. A., Palupi, K. W., \& Fitriani, D. R. (2018). Literasi Media dan Penangkalan Hoax (Studi Fenomenologi Vaksin Campak Rubella). Jurnal Ilmu Komunikasi-MediaKom, 2(1).

Our World in Data. (2021). Data on COVID-19 (coronavirus) vaccinations. Diakses daripada https://ourworldindata.org/covid-vaccinations pada 20 Mei 2020.

Pausé, C., Parker, G., \& Gray, L. (2021). Resisting the problematisation of fatness in COVID-19: In pursuit of health justice. International Journal of Disaster Risk Reduction, 54, 102021.

Perutusan Khas Perdana Menteri (2020). Ucapan Penuh Perutusan Khas Perdana Menteri Mengenai Covid-19, 10 April 2020, Dipetik dari https://www.pmo.gov.my/2020/04/perutusankhas-perdana-menteri-10-april-2020/ pada 25 Ogos 2020.

Rafidah Mat Ruzki. (14 Febuari 2021). Hukum vaksin COVID-19 harus - Mufti Wilayah. Diakses daripada https://www.bharian.com.my/berita/nasional/2021/02/785997/hukum-vaksin-covid-19harus-mufti-wilayah pada 11 Jun 2021.

Ridauddin Daud. (1 Mac 2021). The number of vaccine registration is still low - Khairy Jamaluddin. Diakses daripada https://www.astroawani.com/berita-malaysia/number-vaccineregistration-still-low- khairy- jamaluddin-285431 pada 20 Mei 2021.

Rumetta, J., Abdul-Hadi, H., \& Lee, Y. K. (2020). A qualitative study on parents' reasons and recommendations for childhood vaccination refusal in Malaysia. Journal of Infection and Public Health, 13(2), 199-203.

Rzymski, P., Borkowski, L., Drąg, M., Flisiak, R., Jemielity, J., Krajewski, J., ... \& Fal, A. (2021). The strategies to support the COVID-19 vaccination with evidence-based communication and tackling misinformation. Vaccines, 9(2), 109.

Sannusi, S. N., Ibrahim, F., Shaari, A. H., \& Subhi, N. (2019). Penggunaan media sosial dalam kalangan remaja B40 di sekitar Lembah Klang. Jurnal Komunikasi: Malaysian Journal of Communication, 35(4).

Sheek-Hussein, M., Abu-Zidan, F. M., \& Stip, E. (2021). Disaster management of the psychological impact of the COVID-19 pandemic. International journal of emergency medicine, 14(1), 1-10.

Salathé, M. \& Bonhoeffer, S. The effect of opinion clustering on disease outbreaks. J. R. Soc. Interface 5, 1505-1508.

Sallam, M. (2021). COVID-19 vaccine hesitancy worldwide: A concise systematic review of vaccine acceptance rates. Vaccines, 9(2), 160.

Schuchat, A. (2011). Human vaccines and their importance to public health. Procedia in Vaccinology, $5,120-126$.

Suruhanjaya Pilihan Raya Malaysia. (2017). Laporan Kajian Semula Persempadanan Mengenai SyorSyor Yang dicadangkan Bagi Bahagian-Bahagian Pilihan Raya Persekutuan dan Negeri Di Dalam Negeri Sabah Kali Keenam Tahun 2017. Diakses daripada https://www.spr.gov.my/sites/default/files/Laporan\%20Sabah\%20FINAL.pdf pada 10 Jun 2021.

The Strait Times. (9 Mac 2021). Malaysia maintains target of vaccinating $80 \%$ of population by Feb 2022 despite doubts. Diakses daripada https://www.straitstimes.com/asia/seasia/malaysia- maintains-herd-immunity-goal-by-early-next-year-despite-concerns-over-target pada 21 Mei 2021.

Wirya Khim. (2020). Disaster risk reduction in times of COVID-19: What have we learned?. Food and agriculture organization of the united nations. http://www.fao.org/3/cb0748en/CB0748EN.pdf.

Yamane, T,. (1967). Statistics: An Introductory Analysis, $2^{\text {nd }}$ Edition. New York: Harper And Row. 